\title{
Urbanization level and its effect on the structure and function of homegarden (pekarangan) vegetation in West Java, Indonesia
}

\author{
MUHAMMAD SADDAM ALI ${ }^{1, \boldsymbol{v}}$, HADI SUSILO ARIFIN ${ }^{2, v v}$, NURHAYATI ${ }^{2}$ \\ ${ }^{1}$ Landscape Architecture Program, School of Graduates, Institut Pertanian Bogor. Jl. Meranti, IPB University Darmaga Campus, Bogor 16680, West \\ Java, Indonesia. Tel.: +62-251-8622642, ‘email: saddam_ali@apps.ipb.ac.id, \\ ${ }^{2}$ Landscape Management Division, Department of Landscape Architecture, Faculty of Agriculture, Institut Pertanian Bogor. Jl. Meranti, IPB University \\ Darmaga Campus, Bogor 16680, West Java, Indonesia. Tel.: +62-251-8622642, •`email: hsarifin@apps.ipb.ac.id
}

Manuscript received: 14 October 2020. Revision accepted: 18 December 2020.

\begin{abstract}
Ali MS, Arifin HS, Nurhayati 2021. Urbanization level and its effect on the structure and function of homegarden (pekarangan) vegetation in West Java, Indonesia. Biodiversitas 22: 173-183. Urbanization occurs in West Java Province, Indonesia is currently reducing the ecological value of Indonesian pekarangan or homegardens by decreasing the average area of homegarden and the diversity and abundance of vegetation in them. One study site was in Bogor District, i.e. Selahuni 2, Ciomas Rahayu Village. Four sites in Bogor City, i.e. Sirnagalih-Pagentongan in Loji Village, Tegal Gundil Lama and Tegal Gundil Baru settlements in Tegal Gundil Village, and Baranangsiang Indah Settlement in Katulampa Village. One study site in Cianjur District, i.e. Cibakung Hamlet in Selajambe Village. The objective of this paper is to show the level of urbanization in each area of studies analyzed by Principle Component Analysis (PCA) and the dynamics of homegarden vegetation by comparing data from 1998, 2007, and 2019. The results showed that the levels of urbanization in the six study sites were moderately urbanized and highly urbanized. Homegarden dynamics occurred in the direction of changing homegarden area and the number of species and individuals of plants there. The dynamics of the homegarden due to urbanization have increased the composition of non-ornamental species, mostly fruit plants in all research sites in 2019.
\end{abstract}

Keywords: Fruit plants, householders, non-ornamental plants, plant functions, vertical strata

\section{INTRODUCTION}

Urbanization has positive impacts on a country's economic growth and brings significant benefits such as the creation of employment, education, innovation, welfare, social structure, and institutions (Ochoa et al. 2018). However, the rapid urbanization has caused environmental degradation, climate change, poverty, and injustice, and has changed land use, the diversity of ecosystems, the watershed hydrology, and the biogeochemical cycle through waste disposal (Lin et al. 2015; Schneider et al. 2015; Kalantari et al. 2017). Urbanization continues to occur in many developing countries, especially in Africa and Asia (Cai et al. 2018). In China, the need for employment was a significant factor in the rapid urbanization (Cheng et al. 2015; Gomes et al. 2019; Lu et al. 2019). Research in Chengdu China showed that urban areas increased by more than $350 \%$ between 1978 and 2002 in three different spatial trends near suburban in all directions before 1990, along transportation corridors, ring roads, and near satellite cities (Schneider et al. 2005). Urbanization is characterized by many environmental problems such as loss of biodiversity and the occurrence of urban heat islands (Romero et al. 2012; Liu et al. 2015). Urbanization has changed the global and local resources (Cui et al. 2019). The increasing population in JakartaBogor-Depok-Tangerang-Bekasi (Jabodetabek) due to urbanization has increased demand for housing and other infrastructures (Rustiadi et al. 2015; Robbany et al. 2019).
Urban areas in Jabodetabek increased by $61 \%$ in 2015 (Robbany et al. 2019). That phenomenon also, directly and indirectly, influenced the homegarden.

Among the various components of the rural landscape, the homegarden is an essential part of residential land use (Hakim 2014). Three major themes emerged from the literature about the garden/homegarden for the owner, and one of which was gardens and identity (Mazumdar dan Mazumdar 2012). Garden can express the gardener's relationship with the environment or his/her ecological character (Kiesling dan Manning 2010), and pekarangan is the specific homegarden of Indonesia. A homegarden with edible plants maintains high agrobiodiversity and increases food diversity for households (Van Der Stege et al. 2010). Homegardens produce a variety of plant products such as fruit, vegetable, and other non-timber forest products (Mohri et al. 2013), medicinal plants, shade, and ornamental (Abebe et al. 2010) managed by family (Kumar dan Nair 2004). However, urbanization has a significant detrimental effect on the homegarden area, the structure and function of its vegetation in West Java (Arifin et al. 1997). Some reasons for the deterioration of the homegarden area in West Java are the use of land as a place to build a house, a vehicle parking area, and a selling area, and the close proximity of the village to the city (Azra et al. 2014). Urbanization has reduced the area of homegarden and reduced the number of non-ornamental plants and reduced the structure of stratification of homegarden in West Java (Arifin et al. 1998). 
The aims of this study were to measure the level of urbanization in 6 villages spread across Cianjur District, Bogor District, and Bogor City of West Java Province, Indonesia, and to asses the changes in the structure and function of pekarangan (homegarden) vegetation by comparing the current data with those of the previous studies.

\section{MATERIALS AND METHODS}

\section{Study sites}

The study sites were scattered in Bogor District (Ciomas Rahayu Village), Bogor City (Katulampa Village, Tegal Gundil Village, Loji Village), and Cianjur District (Cibakung, Selajambe Village) in West Java Province, Indonesia. (Figure 1). Site details and the number of pekarangan (homegarden) samples are shown in Table 1. All the study sites were the same as those in two previous studies (1998 and 2007) (Arifin et al. 1998; Mayanti 2007) because it was time-series research.

The choice of site and number of homegarden samples followed the previous research (Arifin et al. 1998). The number of homegarden samples was also adjusted to the size of the study area and the number of houses. These sites were chosen according to the level of urbanization. Baranangsiang Indah, Tegal Gundil Lama, and Tegal Gundil Baru were closed to urban areas, while SirnagalihPagentongan was a suburban area. Cibakung's site was a rural area. A literature study collected data in 1998 from the previous research (Arifin et al. 1998) and data in 2007 from the thesis of Mayanti (2007).

\section{Data collection and analysis}

Analysis of urbanization levels was based on geographical, social, and economic drivers of urbanization (Table 3). Analysis of the dynamics of the structure and function of homegarden vegetation has been done by measuring the area of homegarden samples, recording the name of the plant species, calculating the number of species and individual plants, the vertical and horizontal structure (plant functions) of the vegetation. Therefore, data were processed with descriptive statistics, centralizing the data with graphs or diagram display. The 2019 study results were compared with those of the 1998 and 2007 studies for comparison of urbanization level that occurred. The following procedures were used in this research.

Analysis of the urbanization level was calculated using the Principal Component Analysis (PCA) method (Arifin et al. 1997) using SPSS, a statistical software. The principal component analysis is a multivariate statistical method that selects a small number of components to account for the variance of original multi-response (Fung dan Kang 2005). The data were first standardized (looking for the $\mathrm{z}$ value) and this $\mathrm{z}$ value was used in PCA analysis. PCA analysis divided the data into two components (eigenvalues was 1). Data for nine parameters of urbanization driving factors for this analysis were obtained from interviews with the householder of homegardens, from the central statistics agency, and from previous studies. Data for 2007 were not available because in that year there was no analysis of the level of urbanization.

The average area of homegarden was calculated with the following formula. Then the results were grouped according to the area of green space.

$$
\hat{\mathrm{u}}=\frac{1}{\mathrm{~m}} \sum_{\mathrm{i}=1}^{\mathrm{m}} \text { ui. }
$$

Where:

û : Average area of homegarden

$\mathrm{n}$ : Number of homegarden samples

ui : Area of the $\mathrm{i}^{\text {th }}$ homegarden

Based on the results of research on the position of the homegardens in the upstream, middle, and downstream watersheds in three provinces on Java Island, namely the Provinces of West Java, Central Java, and East Java, the size of homegarden was divided based on the area of its green space, namely (i) small: area of green space $<120 \mathrm{~m}^{2}$, (ii) medium: $120 \mathrm{~m}^{2} \leq$ area of green space $<400 \mathrm{~m}^{2}$, (iii) large: $400 \mathrm{~m}^{2} \leq$ area of green space $<1000 \mathrm{~m}^{2}$, and (d) extra larges: the green space is $\geq 1000 \mathrm{~m}^{2}$ (Mulyana et al. 2007).

The local and scientific names of plant in each homegarden were recorded and distinguished between ornamental plants and non-ornamental plants.

The average number of species in each sample of homegarden was calculated. The data collection of vegetation species in the six research sites was necessary to determine what species were widely planted in the homegardens (v).

$$
\mathrm{S}=\frac{1}{\mathrm{~m}} \sum_{\mathrm{i}=1}^{\mathrm{m}} \text { si }
$$

Where:

$\mathrm{s}$ : Average number of species/pekaranga

$\mathrm{n}$ : Number of homegarden sample

si : Number of species of homegarden-i

The average number of individuals of plants in each homegarden sample and the proportions of the most widely planted species in homegardens were calculated.

$$
\mathrm{k}=\frac{1}{\mathrm{n}} \sum_{\mathrm{i}=1}^{\mathrm{m}} \mathrm{ki}
$$

Where:

û : Average number of individual/homegarden

$\mathrm{n}$ : Number of homegarden samples

ki : Number of individuals of homegarden-i

The vertical stratification (Table 2) of vegetation in each sample homegarden was described.

The plants in each sample of homegarden were classified according to their functions or uses. 


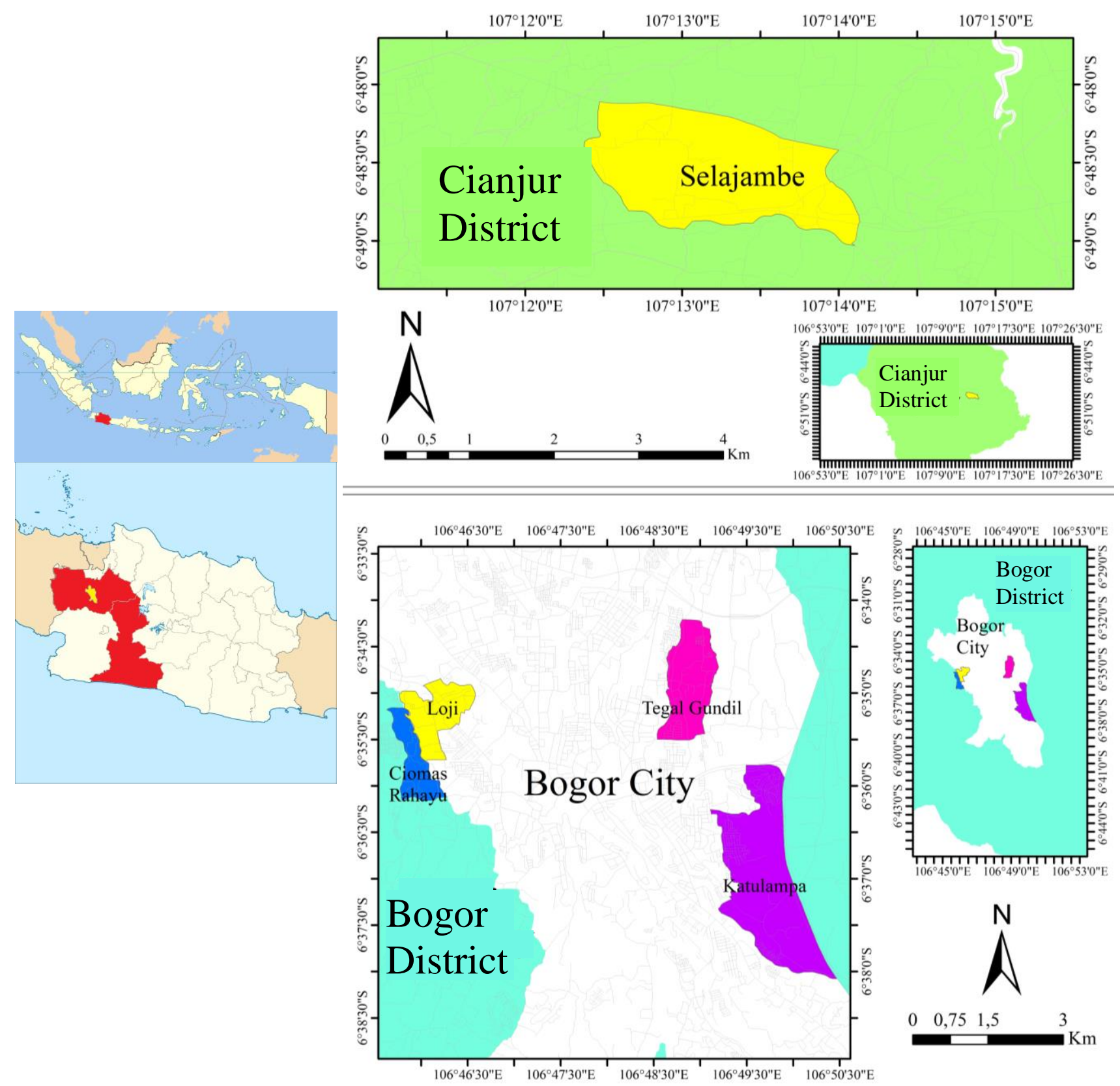

Figure 1. Study site map in West Java, Indonesia

Table 1. Study sites and number of samples

\begin{tabular}{lllc}
\hline \multicolumn{1}{c}{ Study sites } & \multicolumn{1}{c}{ Villages } & District/City & Number of samples \\
\hline Cibakung & Selajambe & Cianjur District & 30 \\
Babakan Sukaningal & Ciomas Rahayu & Bogor District & 10 \\
Sinargalih-Pagentongan & Loji & Bogor City & 21 \\
Tegal Gundil Lama & Tegal Gundil & Bogor City & 20 \\
Tegal Gundil Baru & Tegal Gundil & Bogor City & 10 \\
Baranangsiang Indah & Katulampa & Bogor City & 24 \\
\hline
\end{tabular}


Table 2. Vertical stratification of vegetation and plant functions

$\begin{array}{cl}\text { Vertical strata } & \text { Plant heights } \\ \text { V } & \text { High tree }>10 \mathrm{~m} \\ \text { IV } & 5 \mathrm{~m}<\text { shrub, small tree } \leq 10 \mathrm{~m} \\ \text { III } & 2 \mathrm{~m}<\text { bush, small shrub } \leq 5 \mathrm{~m} \\ \text { II } & 1 \mathrm{~m}<\text { herb, bush } \leq 2 \mathrm{~m} \\ \text { I } & \text { grass, herb, small bush } \leq 1 \mathrm{~m} \\ & \\ \text { Plant functions } & \text { Plant functions }{ }^{2} \\ 1 & \text { Fruit plant } \\ 2 & \text { Vegetable plant } \\ 3 & \text { Spice plant } \\ 4 & \text { Medicinal plant } \\ 5 & \text { Starch-producing plant } \\ 6 & \text { Industrial raw material plant } \\ 7 & \text { Other plants (for fuel woods; handicraft, } \\ & \text { constructed building material, etc) }\end{array}$

Note: ${ }^{1}$ Arifin et al. (2010); ${ }^{2}$ Arifin et al. (2012)

\section{RESULTS AND DISCUSSION}

\section{Urbanization level in the study sites}

The first component, the drivers of urbanization that affected the six study sites the most were the level of education, the use of technology (handphone/smartphone), the increase in the average income, and the increase in the area built (Table 3). In the second component, the driving factors of urbanization that affected the six study sites the most were the reduction in the area of green space and the increase of income.

The results of the PCA analysis in 2019 showed that the study sites were divided into two groups of levels of urbanization only, i.e., less urbanized (L) and more urbanized (M). The I group consisted of I-1 (Cibakung) and I-2 (Selahuni 2), while the $\mathrm{M}$ group consisted of $\mathrm{M}-1$ (Tegal Gundil Baru), M-2 (Baranangsiang Indah), M-3 (Tegal Gundil Lama), and M-4 (Sirnagalih-Pagentongan). Meanwhile, the results of the PCA analysis by Arifin et al. (1998) showed that the study sites were divided into three groups based on the level of urbanization. The first group was the Most Urbanized (M), namely M-1 (Tegal Gundil Baru) and M-2 (Baranang Siang Indah). The second group was Intermediately Urbanized (I), namely I-1 (SirnagalihPagentongan), I-2 (Babakan Sukaningal, now Selahuni 2), and (Tegal Gundil Lama). The third group was the least Urbanized (L), namely L-1 (Cibakung). Changes in the level of urbanization from 1998 to 2019 are presented in Table 4.

\section{Dynamic of average area of homegarden}

The physical dynamics of homegarden can be seen from changes in homegarden area and its size (Figures 3 and 4)Figure 3 shows that the average area of homegarden sample in the six study sites from 1998 to 2007 has decreased. The most significant decline in the average homegarden area occurred at Tegal Gundil Lama, which was $86 \%$, and the smallest homegarden occurred at Tegal Gundil Barut, namely $22.7 \%$. This decrease was triggered by the increasing need for space (buildings), both due to the expansion of the housing and other uses such as a parking garage that took up homegarden areas. From 2007 to 2019 , the average area of homegardens in the study sites Cibakung and Sirnagalih-Pagentongan decreased by $39 \%$ and $36 \%$. In Tegal Gundil Baru, the average homegarden area did not change. Homegarden area in Selahuni 2, Baranangsiang Indah, and Tegal Gundil Lama have increased by $23 \%, 56 \%$, and 17\%. From 2007 to 2019, the changes were more fluctuating.

The existence of the small homegarden size (A) increased in five sites study sites, except in Selahuni 2 there was no increase. It showed that in 2019, the size of the majority of homegardens narrowed from 1998. The number of small-size homegarden increased to above $50 \%$. This increase in the number was due to the decreasing size of other homegardens (medium, large and extra larges) in all study sites. The size of the medium pekaranga (B), large (C), and extra larges (D) in all areas experienced a drastic decrease in percentages, except in Selahuni-2, which increased by $40 \%$. The size of D in all sites decreased by $100 \%$ (no more). This change in homegarden size was triggered due to the expansion of built land that took up the plot of land, so that the medium (B) large (C), and extra larges (D) homegarden sizes were reduced due to changes in their functions. The percentage change in the homegarden size at each site can be seen in Figure 4.

\section{Dynamics of plant species diversity and abundance in homegardens}

The average number of species in each homegarden in the majority decreased from 1998 to 2007 and from 2007 to 2019. The dynamics that occurred were in line with the growing area of settlements in each research site. Besides, the change's level of urbanization from 1998 to 2019 also greatly influenced the number of plant species in the study site. The average change in the number of species in each homegarden is presented in Figure 5.

Figure 5 shows that the average number of species per homegarden decreased in 2007 and 2019, except at Tegal Gundil Baru (in 2007). The biggest decrease occurred at Tegal Gundil Lama in 2007, i.e., 60.0\%, followed by the Selahuni-2, Baranangsiang Indah, Tegal Gundil Baru, Cibakung, and Sirnagalih-Pagentongan, namely $43.75 \%$, $43.24 \%, 4118 \%, 30.56 \%$ and $0.00 \%$, respectively. The biggest decrease occurred at Sirnagalih-Pagentongan in 2019 , namely $63.27 \%$, followed by the site of Tegal Gundil Baru, Tegal Gundil Lama, Selahuni-2, Cibakung, and Baranangsiang Indah, i.e., $40.00 \%, 37.50 \%$, 36.00\%, $33.33 \%$, and $23.81 \%$, respectively. The number of species found at Cibakung was 153, Baranangsiang Indah 149, Sirnagalih-Pagentongan 141, Tegal Gundil Baru 76, Selahuni-2 71, and Tegal Gundil Lama 68. The species found most at each study site were Pleomele elliptica in Cibakung, Cordyline fruticosa in Selahuni-2, Neomarica longifolia in Tegal Gundil Baru, Bromelia sp. in Baranangsiang Indah, Cnidoscolus aconitifolius in Tegal Gundil Lama, and Aerva sanguinolenta in SirnagalihPagentongan. 
These six plants were found the most for several reasons. The community knows Pleomele elliptica as a natural food coloring, so it is still widely used by Sundanese people, especially in rural areas (Downham dan Collins 2000). This plant is widely used as hedge. Aglaonema marantifolium is known as an ornamental pl. Cordyline fruticose is recognized by the Sundanese people not only because of its use as an ornamental and medicinal plant, but also its socio-cultural value. This plant is considered to be strong and sacred, so it is often used as a sign of the existence of something, a space divider, and the hedge of the house (Barker dan Willis 2001). Neomarica longifolia is enjoyed for its beautiful yellow flowers, while Aerva sanguinolenta is known for its beautiful leaves. Both plants are planted simultaneously as a space divider. Bromelia is an ornamental plant enjoyed for its leaf colors and to be the characteristics of tropical gardens and accent in the front yard of the house. Cnidoscolus aconitifolius is known as a new vegetable plant, included in 2007, originating from Central America. Today many people consume this vegetable plant product. The function of homegarden is not only for ornamental, but also for its nonornamental functions. Non-ornamental functions such as for food, medicine and industry. One of the impacts of changes that occur in homegarden is the dynamics of the composition of ornamental and non-ornamental plants.
This change is related to the use of plants for each owner or the owner's preference in presenting or planting these plants in homegarden. The plants planted mainly have economic and aesthetic benefits, so that the presence of these plants provides benefits for the owners of the yard. The dynamics of the number of ornamental and nonornamental plants indicate the trend of plants that occurred in that year (Figure 7).

Table 3. PCA value of the 9 driving factors of urbanization

\begin{tabular}{lcc}
\hline Variables & Comp. 1 & Comp. 2 \\
\hline Distance between research site and & -0.899 & 0.413 \\
nearest city (km) & -0.342 & -0.487 \\
Population density (people.km) & 0.674 & 0.322 \\
Built-up area (ha) & - & 0.792 \\
Green open space (ha) & -0.885 & 0.423 \\
Percentage of farmers (\%) & 0.732 & 0.558 \\
Average population income (rupiah) & -0.795 & -0.449 \\
Percentage of native people (\%) & 0.991 & - \\
Education level (\%) & 0.839 & -0.470 \\
Use of technology (handphone) (\%) & 5.017 & 2.052 \\
Eigenvalue & 55.743 & 22.805 \\
Contribution & 55.743 & 78.548 \\
Cumulative contributions & & \\
\hline
\end{tabular}

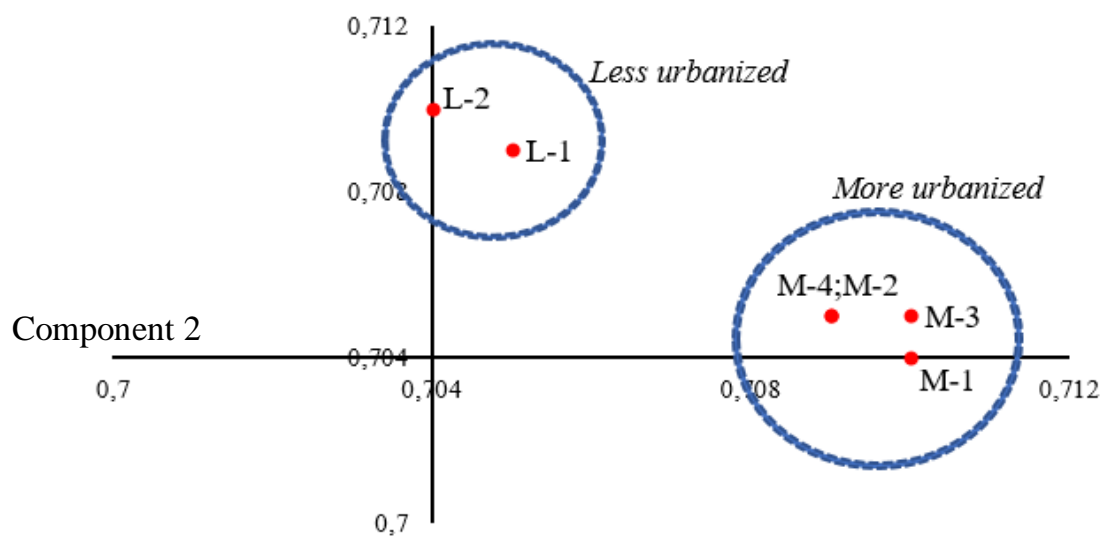

Component 1

Figure 2. The level of urbanization of research sites of West Java, Indonesia in 2019. Note: L: the less urbanized, M: the more urbanized

Table 4. Changes in the level of urbanization of study sites of West Java, Indonesia from 1998 to 2019

\begin{tabular}{llcc}
\hline \multirow{2}{*}{ Old name study sites } & \multirow{2}{*}{ New name study sites } & \multicolumn{2}{c}{ Urbanization level code } \\
\cline { 3 - 4 } Cibakung & Cibakung & $\mathbf{1 9 9 8}$ & $\mathrm{2019}$ \\
Sirnagalih-Pagentongan & Sirnagalih-Pagentongan & $\mathrm{L}-1$ & $\mathrm{~L}-1$ \\
Babakan Sukaningal & Selahuni 2 & $\mathrm{I}-2$ & $\mathrm{~L}-2$ \\
Tegal Gundil Lama & Tegal Gundil Lama & $\mathrm{I}-3$ & $\mathrm{M}-3$ \\
Tegal Gundil Baru & Tegal Gundil Baru & $\mathrm{M}-1$ & $\mathrm{M}-1$ \\
Baranangsiang Indah & Baranangsiang Indah & $\mathrm{M}-2$ & $\mathrm{M}-2$ \\
\hline
\end{tabular}

Note: M: Most Urbanized, I: Intermediately Urbanized, L: Less/least Urbanized 


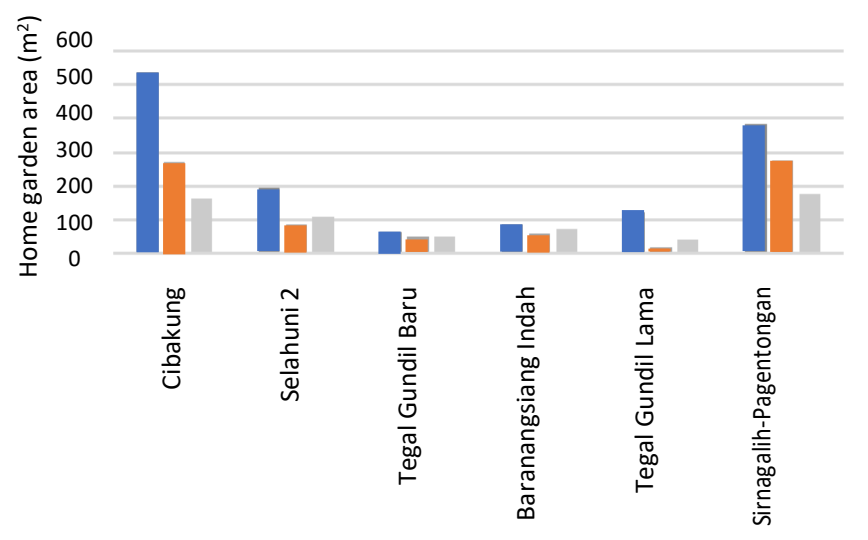

- $1998=2007 \quad 2019$

Figure 3. Average area of homegardens

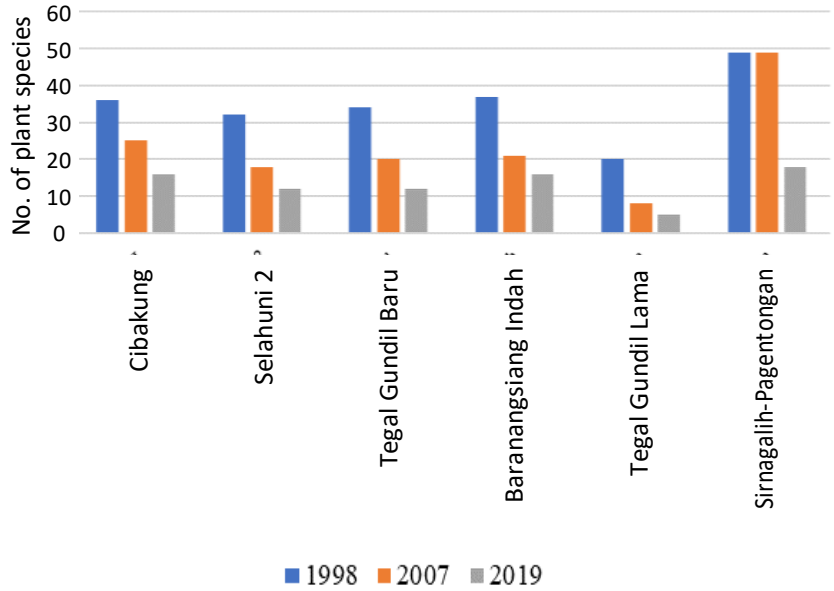

Figure 5. Changes in the number of species in homegarden

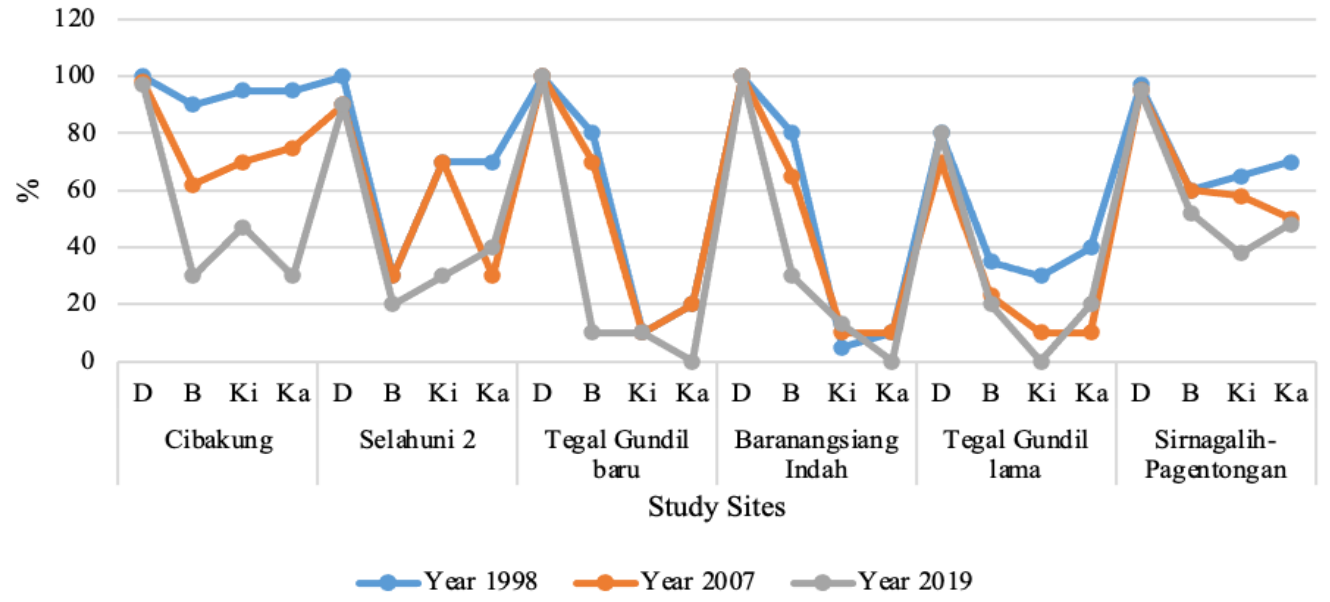

Figure 4. The percentage changes in size of homegardens. Note: A, small: area of green space $<120 \mathrm{~m}^{2} ; \mathrm{B}$, medium: $120 \mathrm{~m}^{2} \leq$ area of green space $<400 \mathrm{~m}^{2}, \mathrm{C}$, large: $400 \mathrm{~m}^{2} \leq$ area of green space $<1000 \mathrm{~m}^{2}$; and $\mathrm{D}$, extra larges: the green space is $\geq 1000 \mathrm{~m}^{2}$

In 1998, the composition of ornamental plants was higher than that of non-ornamental plants in the six study sites, except in Cibakung. The composition of ornamental plants was highest, namely in the Tegal Gundil Baru and Baranangsiang Indah each was 70\%, then in Selahuni 2 wa 58\%, Tegal Gundil Lama and Sirnagalih-Pagentongan each was 55\%, while in Cibakung was 40\%. In 2007, it was seen that the majority of ornamental plants were also higher than non-ornamental plants in the six study sites, except Cibakung and Selahuni 2. The composition of ornamental plants was highest, namely in Tegal Gundil Baru was $75 \%$, then Baranangsiang Indah was 70\%, Tegal Gundil Lama was $62 \%$, and Sirnagalih-Pagentongan was $60 \%$, while in Cibakung and Selahuni 2 each was 45\%. In 2019, the majority of plants in the six study sites were still dominated by ornamental plants, except for Cibakung and Selahuni 2. The highest ornamental plants were in the Baranangsiang Indah site was $65 \%$, then Tegal Gundil Baru was $61 \%$, Sirnagalih-Pagentongan and Tegal Gundil Lama were 54\% and 53\%, respectively, while for the Cibakung and Selahuni 2 sites, it was $44 \%$ and $45 \%$, respectively.

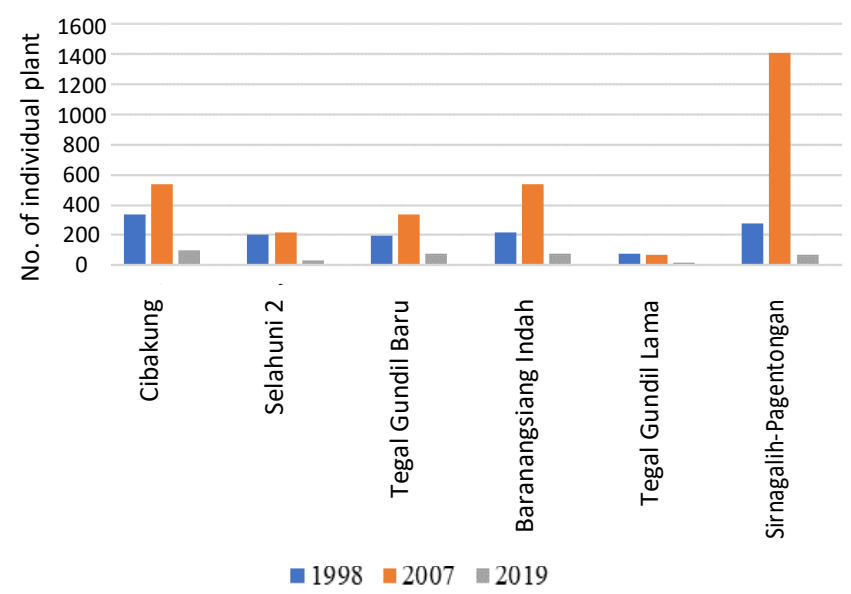

Figure 6. Changes in the number of individuals per homegarden 


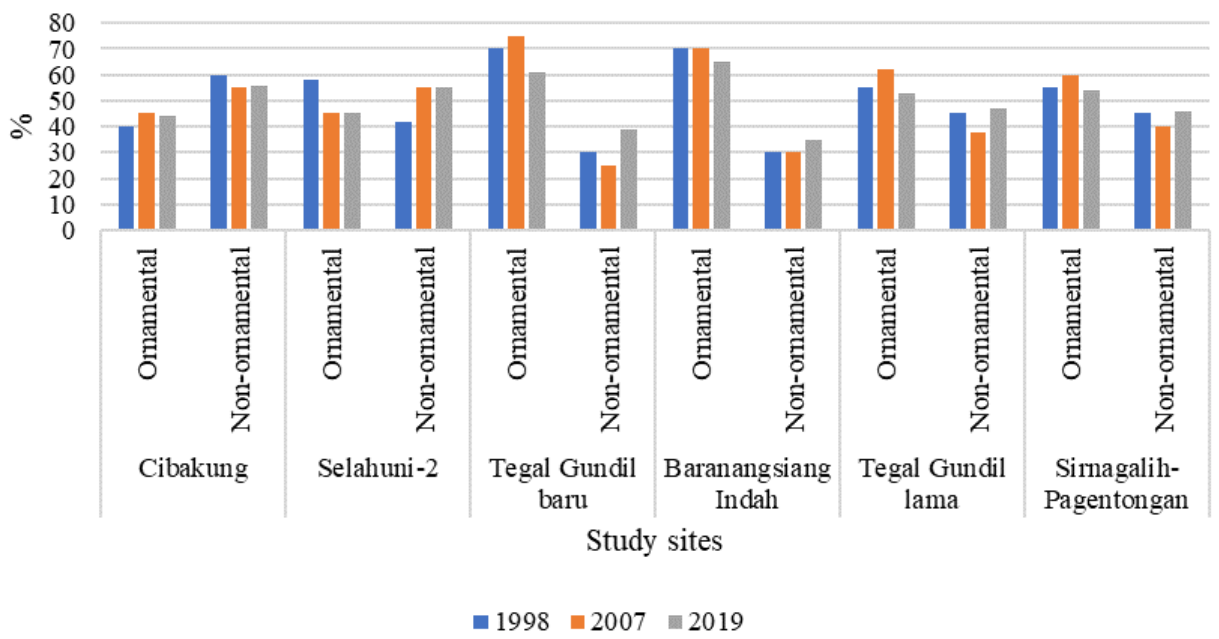

Figure 7. Dynamic of ornamental and non-ornamental plants

There were five surviving ornamental plants, namely Dracaena angustifolia, Cordyline fruticosa, Aglaonema marantifolium, Dieffenbachia picta, and Anthurium crystallinum. The community knows Dracaena angustifolia like Pleomele elliptica as a plant whose leaves are used for natural food coloring, so it is still widely used by Indonesian people, especially Sundanese people who live in rural areas (Downham dan Collins 2000) and this plant also is widely used as hedge. Aglaonema marantifolium is known as an ornamental plant queen because of its graceful habitus, and is believed to be a fortune-carrying plant (Subono dan Andoko 2004; Dewi et al. 2012), so it has high economic value. Dieffenbachia picta and Anthurium crystallinum are popular ornamental plants because of their aesthetic leaf color. These ornamental plants survived because they are relatively easy to grow, and they are widely planted in the front and side yard of the houses.

The number of individuals was the total number of all plant species in the homegardens. In general, the average number of individuals per homegarden increased at six study sites from 1998 to 2007 (except in Tegal Gundil Lama). Then, the majority of the average number of individuals decreased in all study sites from 2007 to 2019. The dynamics occurred in line with the continued increase in the area of settlements in each study site (increasing the number of homegardens and reducing the size of homegarden). Besides, the changing level of urbanization from 1998 to 2019 also greatly influenced the number of individual plants in the study sites. Figure 6 shows the average fluctuation in the number of individuals per homegarden temporarily. In 2007, the largest addition of the largest number of individuals occurred at SirnagalihPagentongan site, i.e., 414.23\%, followed by Baranangsiang Indah, Tegal Gundil Baru, Cibakung, and
Selahuni-2, namely $150.46 \%, 70.92 \%, 59.23 \%$, and $5.88 \%$, respectively. Site of Tegal Gundil Lama experienced a decrease in the number of individuals per homegarden, i.e., $10.67 \%$. In 2019, the largest decline in the number of individuals occurred in Sirnagalih-Pagentongan, i.e., $95.17 \%$, followed by Baranangsiang Indah, Selahuni-2, Cibakung, Tegal Gundil Lama, and Tegal Gundil Baru, namely $85.77 \%, 84.72 \%, 82.06 \%, 79.10 \%$, and $76.42 \%$, respectively.

The number of individuals in Cibakung was 2,886, Baranangsiang Indah 1,847, followed SirnagalihPagentongan 1,570, Tegal Gundil Baru 784, Selahuni-2 308, and Tegal Gundil Lama 286.

\section{Dynamics of plant vertical stratification}

Vertical stratification of homegarden plants was one aspect impacted by urbanization. Vertical stratification shows a variety of plant height in homegarden. Figure 8 shows the dynamics of vertical stratification of plants in the six study sites. The majority of plants in the study sites in 1998, 2007, and 2019 were found at stratum I (grass, small bush $<1$ meter). The stratum I increased in six study sites in 2007, then decreased in 2019. The percentage of plants in stratum II $(1 \mathrm{~m}<$ herb, bush $\leq 2 \mathrm{~m})$, stratum III $(2 \mathrm{~m}<$ bush, small shrub $\leq 5 \mathrm{~m})$, stratum IV $(5 \mathrm{~m}<$ shrub, small tree $\leq 10 \mathrm{~m}$ ), and stratum V (high trees $>10 \mathrm{~m}$ ) in 1998 and 2007 in all study sites were lower than those in 2019. It was due to several reasons, namely (i) changes in composition of plant habits (ii) changes in owner preferences for plants that were popular to be planted in that year, (iii) changes in plant functions, (iv) shift in plant height due to growth during the period of more than 20 years (v) reduced homegarden area due to the addition of buildings. 
Cibakung

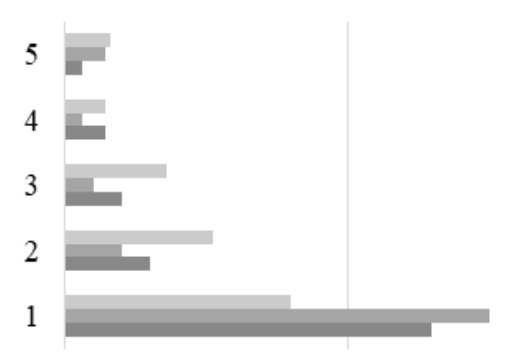

Tegal Gundil Baru

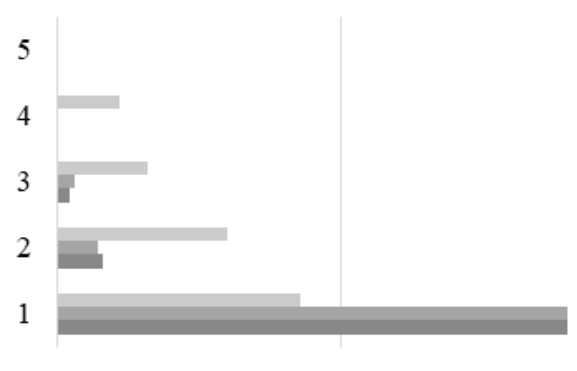

Tegal Gundil Lama

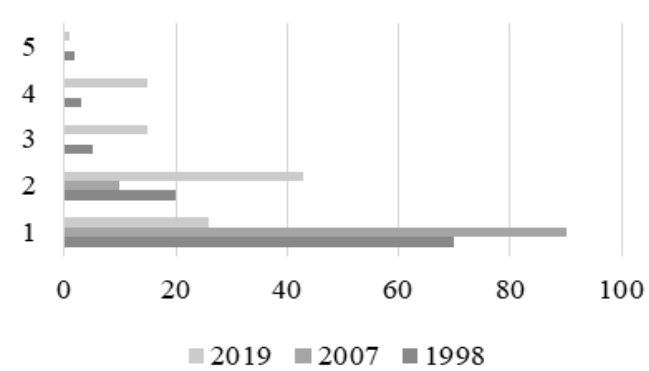

Selahuni-2
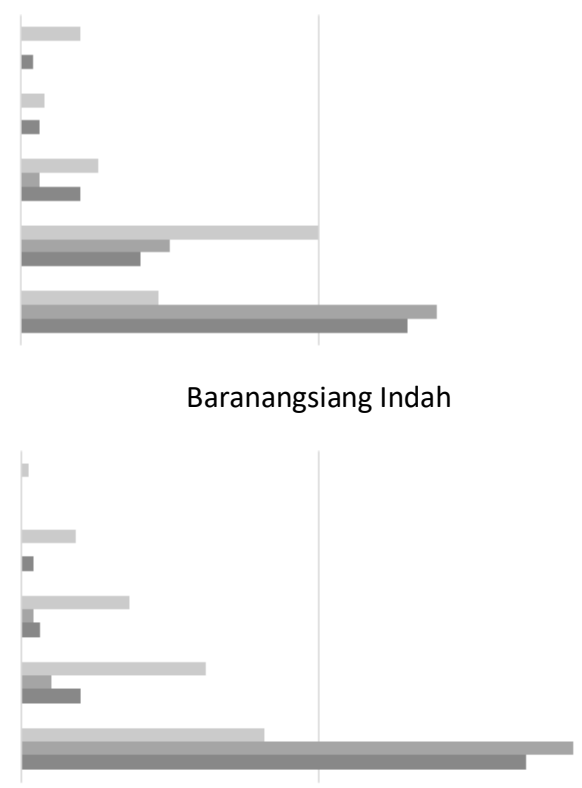

Sirnagalih-Pagentongan

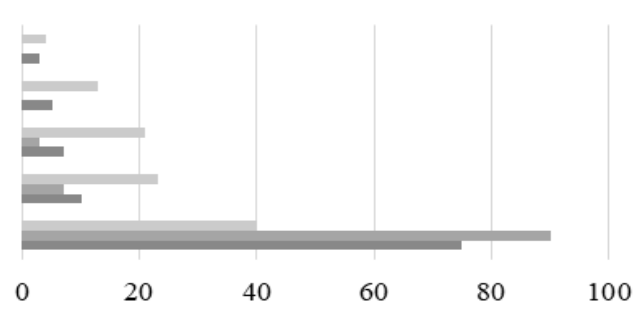

$\because 2019 \square 2007 \quad \square 1998$

Percentage of dynamic (\%)

Figure 8. Percentage of dynamics in plant vertical stratification in 1998, 2007 and 2019

In 2007, it can be seen that in six study sites, except for Cibakung there were no plants in Strata IV and V. It happened because the plants were still included in stratum III within ten years of growth (1998 to 2007) or the trees were felled for building expansion. Tegal Gundil Baru, which were residential areas, in 1998, 2007, and 2019 had no plants in startum $\mathrm{V}$ because the presence of big trees can be dangerous for house building if one day the big trees fall. At that site, there were only plants in stratum IV, which were tall shrubs or small trees that produced beneficial fruit. At Baranangsiang Indah, $1 \%$ of plants in stratum V remained in 2019, but in 1998 and 2007, they were not found. The dominant plants were still in the size of strata III and IV.

At sites Cibakung, Selahuni-2, Tegal Gundil Lama, and Sirnagalih-Pagentongan, the plants in strata IV and V were found and had a relatively high percentage. It was because these plants were still preserved, such as banana, white lead tree, coconut, which have a height of more than $10 \mathrm{~m}$ and had benefits for their householders. Of the four sites, only
Tegal Gundil Lama had the smallest percentage of plants in stratum $\mathrm{V}$, because these sites were organic and very dense settlements. Therefore, it was difficult to find plants in stratum V. Besides, the position of Tegal Gundil Lama is close to Bogor City, so the effect of urbanization was very high. The percentage of plants in strata II and III increased in 2019 in all study sites. Some of the surviving plants in strata III and IV were tall shrubs, ornamental shrubs, and hedgerows. Other plants were fruit-bearing trees, such as guava, sugar apple, and soursop.

\section{Dynamics of plant functions}

Based on their primary functions (Arifin et al. 2012) plants can be categorized as ornamental plants, fruit plants, vegetable plants, herbs, medicinal plants, starch-producing plants, plants for industrial raw materials, and plants for other uses. In this analysis of plant function dynamics, the function of ornamental plants was not included. The fluctuation of the plant functions is shown in Figure 9. 

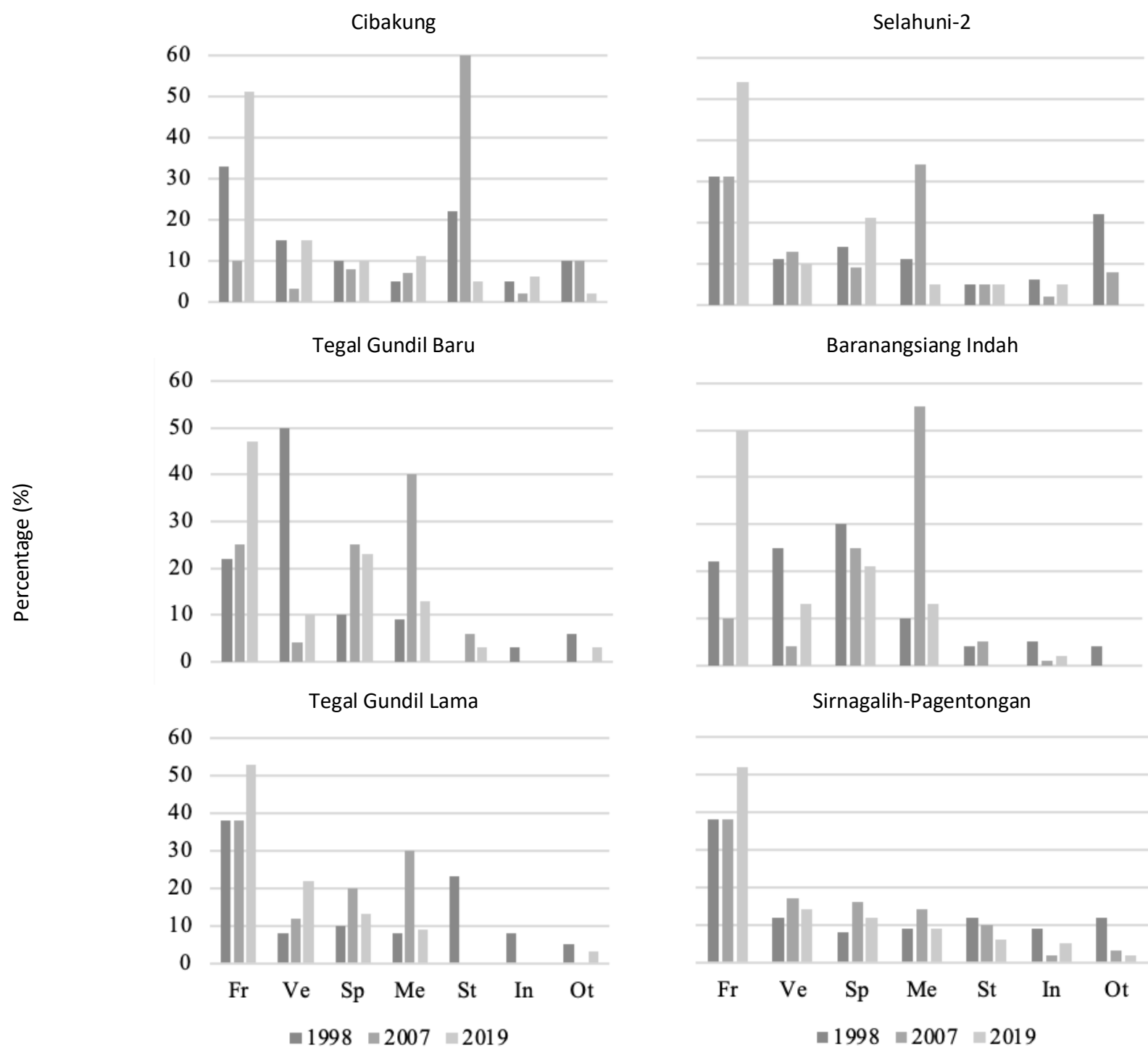

Plant function

Figure 9. Percentage of plant functions other than ornamental plants. Note: Fr: fruit, Ve: vegetable, Sp: Spices, Me: Medicine, St: Starch, In: Industry, Ot: Others

According to 1998 research results, the fruit plants had the highest percentage (33\%), while medicinal plants and industrial raw material plants the lowest $(5 \%)$ in Cibakung study site. In 2007, the starch crops had the highest (60\%), and the industrial plant was the lowest $(2 \%)$. However, in 2019 , the most abundant plants were fruit plants $(51 \%)$, and the lowest were plants for uses other uses $(2 \%)$.

In 1998 and 2007, the plants having the highest abundance varied considerably among the study sites. However, in 2019, all of the plants with the highest percentage were fruit plants. In addition to ornamental plants, fruit plants existed in each homegardensFruit plants widely planted in the homegardens were mangoes, rambutans, and guavas. In addition to fruit plants, herbs were also commonly planted in homegarden, such as turmeric and ginger. Some plants that remained in all study sites in 1998, 2007, and 2019 were Mangifera indica, Nephelium lappaceum, and Syzygium aqueum from the fruit plant group, Pandanus sp., and Capsicum frutescens from spice plant group, and Piper betle from the medicinal plant group.

Rambutan, mango, and guava plants were the most enduring fruit plants in homegarden. Fruit plants survived because they have great benefits, especially food (the need for vitamins and fiber) and a high economic value. The herbs that survived were pandanus and cayenne pepper which were used extensively as culinary ingredients, so their presence in the homegarden continued to be maintained. The medicinal plant that survived in three years of research was the betel plant, known to be useful as a diuretic, anti-inflammatory, and natural antibiotic (Mohri et al. 2013; Lutviandhitarani et al. 2015). In addition to its 
function as a medicinal plant, betel also functions as an ornamental vine, usually used to make pavement look softer.

\section{Discussion}

The increasing level of urbanization in 2019 in Cibakung, Tegal Gundil Lama t, and SirnagalihPagentongan have affected homegarden area and vegetation structure in homegarden. It can be seen from the decreasing area of homegarden, which has decreased the number of species and the number of individual plants. Not only in these 3 sites, in sites with a fixed urbanization level, such as Selahuni-2 (intermediately urbanized), Tegal Gundil Baru settlement and Baranangsiang Indah (the most urbanized) in 1998, urbanization also affected the area of homegarden. It showed that urbanization was a powerful driver of dynamics in homegarden. The effect of urbanization on homegarden is due to population growth and the increasing demand for housing which caused land fragmentation in the homegarden. The first area used to build a house was the homegarden, especially in rural area. The homegarden will be inherited by parents to their children (Azra et al. 2014).

The increasing level of education, the use of technology such as smartphones, the increase in income, which has implications for employment, were socioeconomic factors that affected the level of urbanization in each study site. Economic policies and incentives and the concentration of geographical investment were the driving factors of urbanizations (Seto dan Kaufmann 2003; Seto 2011). The homegarden owner's perspective in looking at homegarden was different from one person to another. Several causes for the decrease of homegarden area were the use of the land for housing, parking lots, shops, and the close proximity of villages to the city (Azra et al. 2014).

The change of level of urbanization level at the Cibakung site is caused by increasing the amount of income because the site is close to the Provincial Highway connected Jakarta-Bandung. Many industrial factories such as garments were built on the sides of the roads, providing job opportunities. Also, many Selajambe Village residents worked as migrant workers abroad. The Selahuni 2 site remained less urbanized because this site was located at the highest altitude among other hamlets in Ciomas Rahayu Village, so the number of houses in 1998 was relatively fixed, despite a lot of housing around that village. In addition, this site is also bordered by the Ciomas river, with a fairly steep land that makes housing expansion difficult (Ali et al. 2020).

The Sirnagalih-Pagentongan site changed from the intermediate to the most urbanized level. Loji developed rapidly into a suburban area because it became part of the City of Bogor. The area was traversed by Gunung Batu street, one of the main access points to Bogor City. Its sloping topography made it possible for massive development, converting existing agricultural lands into housing. The site of Tegal Gundil Lama is the most urbanized because it is very close to the city of Bogor. The increase in the number of house buildings occupying the forest gardens also occurred, such as the area of the river bank. The economic condition that continued to improve marked by the increasing population income is one of the driving factors in increasing the level of urbanization in this site. Tegal Gundil Baru and Baranangsiang Indah are both housing estates, therefore the development and changes in land cover are very fast. The two sites are very close to the center of Bogor City, therefore, both are heavily influenced by the urbanization process from 1998 to 2019. sitessitesThe decrease in the area of the homegarden causes a decrease in the number of plant species that are considered less useful. Therefore, the diversity of homegarden plant species has decreased. It can be seen from the decreasing number of species and individual plants in 2019 compared to 2007 and 1998. The decreasing number of species and individuals has reduced the vertical strata and diversity of plant functions. It can be seen that in 2019, stratum I continued to dominate, but the number was lower compared to 1998 and 2007. In contrast, the other four strata increased in 2019. Plants in these strata are maintained because they have benefits as fruit plants. The increase in the number of plants in strata III, IV, and V in 2019 is due to natural growth. The same plants in 2007 were still small and were in the strata I and II qualifications. In 1998 and 2007, the highest abundance of plant function categories varied considerably among study sites. However, in 2019, fruit plants had the highest percentage in non-ornamental plants indicating that the householder preferred productive plants to aesthetic ones. Besides ornamental plants, fruit plants are available in almost every homegarden. The fruit plants are very important for the diet of household members in terms of vitamins and fiber. Ornamental plants still predominate, although there was a decline between 1998 and 2007 in the homegarden. The predominance of the ornamental plant was also reported in several studies (High dan Shackleton 2000; Coomes dan Ban 2004; Birol et al. 2005; Das dan Das 2005). Fruit plants widely planted in homegarden were mangoes, rambutans, and guavas. In addition to fruit plants, herbs were also commonly planted in homegarden, such as turmeric and ginger. At the M-1 and M-2 sites, several homegarden owners utilized simple technology in using the homegarden by planting fruit plants in pots and using hydroponic techniques to grow vegetables. There were still no programs from the government in six research sites to support food diversity through the homegarden. The majority of these fruit plants occupied strata III, IV, and V (height above 2 meters). They also have an ecological function by providing shade in homegarden and improving the microclimate. Therefore, urbanization has changed the average area of the homegarden, the number of nonornamental plants, and the structure of homegarden stratification in West Java (Arifin et al. 1998; Azra et al. 2014).

However, in this research, the dynamics of homegarden due to urbanization have increased the composition of nonornamental plants, especially fruit plants, and other nonornamental plants in all research sites in 2019. It was recommended that these essential fruit plants be planted in homegarden to make the homegardens sustainable and productive. 


\section{ACKNOWLEDGEMENTS}

Our gratitude delivers to the Ministry of Research Technology and Higher Education/BRIN of Republic of Indonesia through the PMDSU scholarship for funding this research.

\section{REFERENCES}

Abebe T, Wiersum KF, Bongers F. 2010. Spatial and temporal variation in crop diversity in agroforestry homegardens of southern Ethiopia. Agrofor Syst 78: 309-322.

Ali, MS, Arifin HS, Arifin, NHS. 2020. Dinamika pekarangan Kampung Selahuni 2, Desa Ciomas Rahayu, Bogor. J Nat Resour Environ Manag 10(3):364-373. [Indonesian]

Arifin HS, Arifin NHS, Munandar A, Kaswanto. 2010. Pemanfaatan Pekarangan di Perdesaan. Kementerian Petanian RI, Jakarta. [Indonesian]

Arifin HS, Munandar A, SchultinK G, Kaswanto RL. 2012. The role and impacts of small-scale, homestead agroforestry systems (pekarangan) on household prosperity: an analysis of agro-ecological zones of Java, Indonesia. Intl J Agri Sci 2 (10): 896-914

Arifin HS, Sakamoto K, Chiba K. 1997. Vegetation in the homegarden pekarangan in West Java, Indonesia. Bull Intl Assoc Landsc Ecol 3: $38-40$

Arifin HS, Sakamoto K, Chiba K. 1998. Effects of urbanization homegardens on the vegetation Java, structure of in West Indonesia. Jpn J Trop Agric 42 (2): 94-102

Azra ALZ, Arifin HS, Astawan M, Arifin NHS. 2014. Analisis karakteristik pekarangan dalam mendukung penganekaragaman pangan keluarga di Kabupaten Bogor. J Lanskap Indonesia 6 (2): 112. [Indonesian]

Barker CA, Willis P. 2001. Cultural Studies: Theory and Practice. $5^{\text {th }}$ ed. SAGE Publications, London.

Birol E, Bela G, Smale M. 2005. The role of homegardens in promoting multi-functional agriculture in Hungary. EuroChoices 4 (3): 14-21.

Cai Y, Selod H, Steinbuks J. 2018. Urbanization and land property rights. Reg Sci Urban Econ 70: 246-257.

Cheng L, Xia N, Jiang P, Zhong L, Pian Y, Duan Y, Huang Q, Li M. 2015. Analysis of farmland fragmentation in China Modernization Demonstration Zone since "Reform and Openness": A case study of South Jiangsu Province. Sci Rep 5: 11797. DOI: 10.1038/srep11797.

Coomes OT, Ban N. 2004. Cultivated plant species diversity in homegardens of an Amazonian peasant village in northeastern Peru. Econ Bot 58 (3): 420-434.

Cui X, Fang C, Liu H, Liu X. 2019. Assessing sustainability of urbanization by a coordinated development index for an Urbanization-Resources-Environment complex system: A case study of Jing-Jin-Ji region, China. Ecol Indic 96: 383-391.

Das T, Das AK. 2005. Inventorying plant biodiversity in homegardens: A case study in Barak Valley, Assam, North East India. Curr Sci 89 (1) 155-163.

Dewi IS, Wahyuni DK, Purnobasuki H. 2012. Perkembangan kultur daun Aglaonema sp. var siam pearl Aglaonema sp. var Lady Valentin dan Aglaonema sp. var Lipstik dengan perlakuan zat pengatur tumbuh IAA dan BAP. J Biol Res 17 (2): 197-203. [Indonesian]

Downham A, Collins P. 2000. Colouring our foods in the last and nex millennium. Int J Food Sci Technol 35 (1): 5-22.

Fung CP, Kang PC. 2005. Multi-response optimization in friction properties of PBT composites using Taguchi method and principal component analysis. J Mater Process Technol 170 (3): 602-610.

Gomes E, Banos A, Abrantes P, Rocha J, Kristensen SBP, Busck A. 2019 Agricultural land fragmentation analysis in a peri-urban context: From the past into the future. Ecol Indic 97: 380-388.

Hakim L. 2014. Etnobotani dan Manajemen Kebun-Pekarangan Rumah Etnobotani dan Manajemen Kebun-Pekarangan Rumah: Ketahanan Pangan, Kesehatan dan Agrowisata. Penerbit Selaras, Malang. [Indonesian]
High C, Shackleton CM. 2000. The comparative value of wild and domestic plants in homegardens of a South African rural village. Agrofor Syst 48 (2): 141-156

Kalantari Z, Ferreira CSS, Walsh RPD, Ferreira AJD, Destouni G. 2017. Urbanization development under climate change: Hydrological responses in a peri-urban Mediterranean catchment. L Degrad Dev 28 (7): 2207-2221

Kiesling FM, Manning CM. 2010. How green is your thumb? Environmental gardening identity and ecological gardening practices. J Environ Psycho. 30 (3): 315-327.

Kumar B, Nair P. 2004. The enigma of tropical homegardens. Agrofor Syst 61 (1-3): 135-152.

Lin BB, Philpott SM, Jha S. 2015. The future of urban agriculture and biodiversity-ecosystem services: Challenges and next steps. Basic Appl Ecol 16 (3): 189-201.

Liu X, Li Z, Liao C, Wang Q, Zhu A, Li D, Li Y, Tang Z. 2015. The development of ecological impact assessment in China. Environ Intl 85: 46-53.

Lu H, Xie H, Yao G. 2019. Impact of land fragmentation on marginal productivity of agricultural labor and non-agricultural labor supply: A case study of Jiangsu, China. Habitat Intl 83: 65-72.

Lutviandhitarani G, Harjanti DW, Wahyono F. 2015. Green antibiotic daun sirih (Piper betle L.) sebagai pengganti antibiotik komersial untuk penanganan mastitis. J Agripet 15 (1): 28-32. [Indonesian]

Mayanti R. 2007. Studi Dinamika Struktur Vegetasi pada Pekarangan di Jawa Barat (Studi Kasus: Cibakung, Sirnagalih-Pagentongan, Babakan Sukaningal, Tegal Gundil Pemukiman Lama, Tegal Gundil Pemukiman Baru, dan Baranangsiang Indah). [Thesis]. Institut Pertanian Bogor, Bogor. [Indonesian]

Mazumdar S, Mazumdar S. 2012. Immigrant homegardens: Places of religion, culture, ecology, and family. Landsc Urban Plan 105 (3): 258-265.

Mohri H, Lahoti S, Saito O, Mahalingam A, Gunatilleke N, Irham, Hoang VT, Hitinayake G, Takeuchi K, Herath S. 2013. Assessment of ecosystem services in homegarden systems in Indonesia, Sri Lanka, and Vietnam. Ecosyst Serv 5: 124-136.

Mulyana R, Alikodra HS, Arifin HS, Prasetyo LB. 2007. Karakteristik bangunan rumah dan bentuk permukiman di wilayah DAS Cianjur, Jawa Barat. J Sains dan Teknol EMAS 17 (3): 213-226. [Indonesian]

Ochoa JJ, Tan Y, Qian QK, Shen L, Moreno EL. 2018. Learning from best practices in sustainable urbanization. Habitat Intl 78: 83-95.

Robbany IF, Gharghi A, Traub K-P. 2019. Land use change detection and urban sprawl monitoring in metropolitan area of Jakarta (Jabodetabek) from 2001 to 2015. KnE Eng 2019: 257-268.

Romero H, Vásquez A, Fuentes C, Salgado M, Schmidt A, Banzhaf E. 2012. Assessing urban environmental segregation (UES). the case of Santiago de Chile. Ecol Indic 23: 76-87.

Rustiadi E, Pribadi DO, Pravitasari AE, Indraprahasta GS, Iman LS. 2015. Jabodetabek megacity: From city development toward urban complex management system. In: Yadav P, Bhagat RB, In: Singh RB (eds). Urban Development Challenges, Risks and Resilience in Asian Mega Cities. Springer, Japan.

Schneider A, Mertes CM, Tatem AJ, Tan B, Sulla-Menashe D, Graves SJ, Patel NN, Horton JA, Gaughan AE, Rollo JT. 2015. A new urban landscape in East-Southeast Asia, 2000-2010. Environ Res Lett 10 (3): 1-14.

Schneider A, Seto KC, Webster DR. 2005. Urban growth in Chengdu, western China: Application of remote sensing to assess planning and policy outcomes. Environ Plan B Plan Des 32 (3): 323-345.

Seto KC. 2011. Exploring the dynamics of migration to mega-delta cities in Asia and Africa: Contemporary drivers and future scenarios. Glob Environ Chang 21 (1): S94-S107.

Seto KC, Kaufmann RK. 2003. Modeling the drivers of urban land-use change in the Pearl River Delta, China: Integrating remote sensing with socioeconomic data. Land Econ 79 (1): 106-121.

Subono M, Andoko A. 2004. Meningkatkan Kualitas Aglaonema Sang Ratu Pembawa Rezeki. Agromedia Pustaka, Jakarta. [Indonesian]

Van Der Stege C, Vogl-Lukasser B, Vogl CR. 2010. The role of homegardens in strengthening social-ecological resilience: Case studies from Cuba and Austria. In: Plieninger T, Bieling C, (eds) Resilience and the Cultural Landscape: Understanding and Managing Change in Human-Shaped Environments. Cambridge University Press, London. 